\title{
US GEOLOGICAL SURVEY RADIOCARBON DATES XIII
}

\author{
ELLIOTT SPIKER, LEA KELLEY, and MEYER RUBIN
}

US Geological Survey, National Center 971, Reston, Virginia

This list contains the results of some measurements made between 1965 and 1973. Samples are counted in the form of acetylene gas, as previously, and ages computed on the basis of the Libby half-life, $5568 \pm 30$ years. The dates have not been corrected for fractionation by a $\delta^{13} \mathrm{C}$ measurement. The error listed, always larger than the one-sigma statistical counting error commonly used, takes into account possible fractionation in the laboratory and in nature and the variability experienced with replicate samples. We wish to thank Charles Oman for his technical assistance.

Unless otherwise stated, collectors of all samples are members of the US Geological Survey.

\section{A. Eastern United States}

W-2304. East Canaan, Connecticut

$>\mathbf{3 8 , 0 0 0}$

Organic nodules composed of partially decomposed wood, alt $252 \mathrm{~m}$, exposed in forest beds at East Canaan Delta, $0.3 \mathrm{~km}$ NNW of intersection of Rte 44 and Canaan Valley Rd, East Canaan $\left(42^{\circ} 01.0^{\prime} \mathrm{N}, 73^{\circ} 16.6^{\prime} \mathrm{W}\right)$, Connecticut. Coll 1968 by J T Leftwich, L B Smith, W S Newman, J H Hartshorn; subm by G W Holmes. Comment (GW): age is anomalously old for these glacial-deltaic sediments which should date ca 13,000 вР. The organic material is allochthonous, possibly brought in from older deposits, as was noted for similar dates from this area: 28,000 \pm 1000 and $>33,000$, W-2043, -2174 (R, 1970, v 12, p 319).

\section{Wononpakook Lake series, Connecticut}

Samples from swamp, E of Wononpakook Lake $\left(41^{\circ} 56.3^{\prime} \mathrm{N}, 73^{\circ}\right.$ 27.9' W), Connecticut. Coll 1968 by Cornelia Cameron; subm by G W Holmes.

W-2401.

$3980 \pm 250$

Fresh peat, depth $368 \mathrm{~cm}$, underlain by clayey peat.

W-2398.

$\mathbf{8 4 8 0} \pm 300$

Peaty clay, depth $762 \mathrm{~cm}$, underlain by "glacial" clay. Comment (GWH): represents earliest organic deposition after "glacial" lake clay.

\section{Burlington series, Vermont}

Wood and shells from blue-gray silt and clay unit, depth $4 \mathrm{~m}$, drainage trench, Lund Home, Burlington (44 $27^{\prime} 30^{\prime \prime} \mathrm{N}, 73^{\circ} 12^{\prime} 30^{\prime \prime} \mathrm{W}$ ), Vermont. Coll 1968 and subm by A S Hunt and W P Wagner, Univ Vermont, Burlington, Vermont.

W-2309.

$10,950 \pm 300$

Wood. 
W.2311.

$11,420 \pm 350$

Pelecypods.

General Comment (ASH \& WPW): ages are comparable to other Champlain Sea dates.

\section{W-2128. Hemenway Landing, Massachusetts}

Carbonized wood chips, depth $24.6 \mathrm{~m}$, at contact of gray clayey silt overlying light gray sand, Hemenway Landing $\left(41^{\circ} 49^{\prime} 19^{\prime \prime} \mathrm{N}, 69^{\circ} 57^{\prime}\right.$ 55" W), Massachusetts. Coll 1967 and subm by J E Cotton. Comment (JEC): minimum date for end of fluvial sequence and beginning of lacustrine sequence.

\section{Kittatinny Mountain series, New Jersey}

Carbonaceous samples coll from a peat bog, depression in main ridge, Kittatinny Mt, Sussex Co $\left(41^{\circ} 14^{\prime} 08^{\prime \prime} \mathrm{N}, 74^{\circ} 42^{\prime} 10^{\prime \prime} \mathrm{W}\right)$, New Jersey were dated to allow regional correlation of its pollen stratigraphy (Sirkin \& Minard, 1972).

W-2236.

$7800 \pm 650$

Brown reed and sedge peat intermixed with organic muck, depth 5.1 to $5.4 \mathrm{~m}$ in bog. Coll and subm 1968 by J P Minard.

W-2562.

$12,300 \pm 300$

Gyttja, depth 5.5 to $5.75 \mathrm{~m}$, at contact with clay. Coll 1970 by L A Sirkin and subm by $\mathrm{J} P$ Minard.

General Comment (LAS \& JPM): dates are consistent with sample from $3 \mathrm{~m}$ depth, $6260 \pm 300, \mathrm{~W}-2200(\mathrm{R}, 1970, \mathrm{v} 12, \mathrm{p} 320)$. Sedimentation in bog probably begun sometime between 15,000 and 18,300 yr ago as deglaciation of area began.

\section{W-2307. Shackleford Banks, North Carolina}

Peat overlying stained sand zones, Shackleford Banks beach at hightide mark, ocean side (34 $39^{\prime} 30^{\prime \prime} \mathrm{N}, 76^{\circ} 34^{\prime} 25^{\prime \prime} \mathrm{W}$ ), North Carolina. Coll 1968 and subm by P J Godfrey, Natl Park Service, Beaufort, North Carolina. Comment (PJG): site represents ancient position of a freshwater, wooded swamp when Outer Banks were farther from the mainland than they are today.

\section{W-2344. Augusta, Kentucky}

Wood in till exposed on Rte 8 near Augusta $\left(38^{\circ} 46^{\prime} 18.2^{\prime \prime} \mathrm{N}, 83^{\circ}\right.$ $59^{\prime} 14.4^{\prime \prime}$ W), Kentucky. Coll and subm 1969 by W F Outerbridge. Comment (WFO): till has long been considered Illinoian (McFarlan, 1943, p 127), but rock in this cut and wood were so fresh, to the extent that termites were invading, that I thought it might be younger.

\section{W-2320. Tailbace Canal, Alabama}

$>37,000$

Lignitized wood in gravelly sand at base of Quaternary alluvium, depth 12m, near head of Tailbace Canal, Ellmore Co $\left(32^{\circ} 35^{\prime} \mathrm{N}, 86^{\circ} 31^{\prime}\right.$ 
30" W), Alabama. Coll 1968 by John Winefordner and Clayton Gore, both of Alabama Power Co, Alabama; subm by L C Conant. Comment (LCC): minimum date for extensive flood plain of Alabama R. Flood plain from which this sample came is lowest of a succession of some half dozen or more terraces that reach at least $120 \mathrm{~m}$ higher. Date suggests that some low terraces of river system may be Tertiary.

\section{Atlantic continental shelf series}

Dolomite samples from Atlantic Ocean. Subm 1969 by J C Hathaway.

W-2323.

$>40,000$

Depth 400m, Lydonia Canyon (40² 24.5' N, 67 39.1' W). Coll 1968 by J C Hathaway, using DSRV Alvin.

W-2322.

$>40,000$

Depth $180 \mathrm{~m}$, dredged from wall of Hudson Cianyon $\left(39^{\circ} 30.0^{\prime} \mathrm{N}\right.$, $\left.72^{\circ} 15.0^{\prime} \mathrm{W}\right)$. Coll 1968 by Capt Henry W Climm, of fishing vessel, Capn Bill IV

W-2416.

$>33,000$

Complete re-run of $\mathrm{W}$-2322.

General Comment (JCH): these dolomites are not genetically related to aragonite of $20,400 \pm 800, \mathrm{~W}-2170(\mathrm{R}, 1970, \mathrm{v} 12, \mathrm{p} 319)$ as previously thought. Microfauna in sample indicate cold water environment. Stratigraphic position suggests post Tertiary age.

\section{B. Central United States}

\section{W-2305. Long Lake, South Dakota}

$9220 \pm 300$

Pelecypods from collapsed outwash deposited over stagnation moraine (Cilayton, 1962), E side of State Hwy 101, $8.6 \mathrm{~km} \mathrm{~N}$ of Long Lake $\left(45^{\circ} 51^{\prime} 09^{\prime \prime} \mathrm{N}, 99^{\circ} 12^{\prime} 15^{\prime \prime} \mathrm{W}\right)$, South Dakota. Coll 1968 by C M Christensen, J K Hawley, and K C Christensen; subm by C M Cihristensen, South Dakota Geol Survey, Vermillion, South Dakota. Comment (CMC): date compares favorably with several dates from stagnation drift on Coteau du Missouri in North Dakota, $9000 \pm 300$ and $9870 \pm 290$, W-1019, $-954(\mathrm{R}, 1964, \mathrm{v} 6, \mathrm{p} 46)$ and further substantiates theory that stagnant ice was still melting as late $9000 \mathrm{BP}$.

\section{W-2388. East Stump Lake, North Dakota}

$920 \pm 200$

Wood fragments, depth 9 to $11 \mathrm{~m}$ near contact between lacustrine sediments and glacial till, $\mathrm{N}$ end East Stump Lake, Nelson Co $\left(47^{\circ} 54^{\prime}\right.$ 47" N, $98^{\circ} 23^{\prime} 25^{\prime \prime} \mathrm{W}$ ), North Dakota. Coll 1969 by J S Downey; subm by $\mathrm{Q} F$ Paulson. Comment (QFP): date probably indicates beginning of latest period of deposition in lake basin. Possibly date represents end of extremely arid period when lake received little, if any, overland flow or ground-water discharge. 
Wood fragments recovered from drill cuttings, depth $93 \mathrm{~m}$, base of glaciofluvial deposits in buried bedrock channel, Ward Co, North Dakota. Coll 1969 by M O Lindvig; subm by Q F Paulson. Comment (QFP): glacial drift in channel was probably part of interglacial drainage system.

\section{W-2386. Nederlo Creek, W isconsin}

$1130 \pm 200$

Birch log protruding from stream bank at water level, underlying

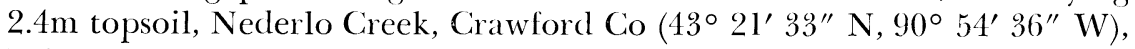
Wisconsin. Coll and subm 1969 by S M Hindall. Comment (SMH): $\log$ was found under $0.6 \mathrm{~m}$ light (modern) silt of loessial origin and $1.8 \mathrm{~m}$ darker, clayey silt of Holocene age. Lighter material essentially represents upland sheet erosion, probably within last $100+$ yr or during time of extensive soil cropping without conservation practices. Darker material represents post-Pleistocene deposits from combined prairie-woodland environment that was indigenous to area prior to cultivation.

\section{W-2357. Slab City, Wisconsin}

$12,200 \pm 350$

Spruce log overlain by $3.6 \mathrm{~m}$ till in borrow pit, $0.8 \mathrm{~km} \mathrm{SW}$ of Slab City, Shawano Co $\left(44^{\circ} 43^{\prime} \mathrm{N}\right.$, $\left.88^{\circ} 27^{\prime} \mathrm{W}\right)$, Wisconsin. Coll 1964 and subm by R F Black, Univ Wisconsin, Madison, Wisconsin. Comment (RFB): this Two Creeks material near outer margin of Valderian ice compares with others from area (Black \& Rubin, 1967-68) and 11,560 $\pm 350, \mathrm{~W}-2015$ (R, 1970, v 12, p 323) and 12,410 \pm 100 , WIS-347 (R, 1970, v 12, p 342).

\section{W-2370. Ruble, Iowa}

$>\mathbf{3 0 , 0 0 0}$

Wood, flattened in cross sec, in till exposed in a well, Ruble, Plymouth Co $\left(42^{\circ} 48^{\prime} 30^{\prime \prime} \mathrm{N}, 96^{\circ} 24^{\prime} 30^{\prime \prime} \mathrm{W}\right)$, Iowa. Coll 1967 by Dennis Carlson, South Dakota Geol Survey, Vermillion, South Dakota; subm by F V Steece, SDGS. Comment (FVS): age indicates that enclosing till is pre-Farmdalian. Regional studies in SE South Dakota and adjacent parts of Iowa and Minnesota indicates that till is Illinoian (Steece, 1965). This date correlates well with clate of $>35,000, \mathrm{~W}-1969$ (R, 1969, v 11, p 212) which is from same surface till of Illinoian age. Area is adjacent to and continuous with a region mapped as Illinoian in South Dakota but separated by Big Sioux R.

\section{Western United States}

\section{W-2289. Yellowstone Lake, Wyoming}

$10,360 \pm 350$

Peaty clay, depth 85 to $104 \mathrm{~cm}$, NE sicle of pond, $0.8 \mathrm{~km}$ of Trail Creek patrol cabin, SE arm of Yellowstone Lake, Yellowstone Natl Park $\left(44^{\circ} 18^{\prime} \mathrm{N}, 110^{\circ} 14^{\prime} \mathrm{W}\right)$, Wyoming. Coll 1966 and subm by R G Baker. Comment (RGB): minimum date for period when Yellowstone Lake was $27 \mathrm{~m}$ higher than present level (Baker, 1976; Spiker et al, 1977).

\section{Hanford region series, Washington}

Geol investigations were conducted in S-central Washington to resolve differing interpretations concerning faulting and tectonic move- 
ments (Bingham et al, 1970). Samples were coll and subm 1969 by J W Bingham.

\section{W-2363.}

$11,950 \pm 300$

Carbonaceous silt deposited as lens, $369 \mathrm{~m}$ above MSL, backhoe trench, Smyrna Bench, N side of Saddle Mts, Grant Co $\left(46^{\circ} 49^{\prime} 40^{\prime \prime} \mathrm{N}\right.$, $\left.119^{\circ} 33^{\prime} 40^{\prime \prime} \mathrm{W}\right)$. Comment (JWB): provides limit for 2 events. 1)ated material occurs near bottom of loess filling large trough. Trough was probably caused by pulling apart of bounding caliche and fanglomerate during large block slide. Sliding probably occurred at end of or cluring last glaciofluvial flooding down Crab Creek. This indicates that trough, as well as many small cracks, was opened up a relatively short time before $12,000 \mathrm{BP}$ and that glaciofluvial flooding ceased before that date. Second event is volcanic ash deposition, which occurred shortly after 12,000 вP. If ash is from Glacier Peak, date becomes critical because Glacier Peak ash has previously been considered to be 12,000 to $13,000 \mathrm{BP}$ and to be within latest glaciofluvial flood episode.

\section{W-2310.}

Wood embedded in medium to coarse sand within a sequence of well-bedded sand and gravels, alt $192 \mathrm{~m}$, bulldozer trench, S side of Gable Mt, Hanford Works Reservation, Benton Co $\left(46^{\circ} 35^{\prime} 40^{\prime \prime} \mathrm{N}, 119^{\circ} 29^{\prime}\right.$ 25" W). Coll by R E Brown of Battelle Northwest, Washington, and J W Bingham. Comment (JWB): unit dated is 2nd oldest of 4 exposed glaciofluvial units deposited by floodwater of Glacial Lake Missoula (Richmond et al, 1965), Upper 2 deposits were dated elsewhere at ca 20,000 , and 13,500 to $12,000 \mathrm{BP}$.

W-2168. Newberry volcano, Oregon

$1720 \pm 250$

Wood underlying main pumice fall from Central Pumice Cone in Newberry Caldera, $40 \mathrm{~km} \mathrm{~S}$ of Bend $\left(43^{\circ} 44^{\prime} \mathrm{N}, 121^{\circ} 14^{\prime} \mathrm{W}\right)$, Oregon. Coll 1968 by Mike Higgins; subm by Arthur Grantz. Comment (AG): compares favorably with age, $2054 \pm 230$ (Peterson \& Groh, 1965, p 11) from charcoal in ash inside caldera.

\section{Corral Canyon series, California}

Samples dated in attempt to arrive at a recurrence interval for land movement in Corral Canyon area $\left(34^{\circ} 00^{\prime} \mathrm{N}, 118^{\circ} 45^{\prime} \mathrm{W}\right)$. Exact relations of each sample to possible movement is very complex and is cletailed in Yerkes and Wentworth (1965), and Birkeland (1974, p 148). Samples coll 1965 and 1968 by P W Birkeland, Univ Colorado, Boulder, Colorado and $\mathrm{C} M$ Wentworth.

\section{W-1634.}

Shells (Mytilus californianus, septifer bifurcatus) from silty sand, Trench 3. 
W-1635.

Carbonaceous clay along slip surface, $24 \mathrm{~m}$, NW wall of Trench 3 .

W-1678.

$3080 \pm 250$

Soil from $\mathrm{S}$ end of Trench B, bottom of soil horizon in alluvial fan.

W-1637.

$4050 \pm 300$

Organic clay from top of same soil horizon, Trench B.

W-1645.

$9330 \pm 400$

Organic clay from base of same soil horizon, Trench B.

W-2328.

$16,280 \pm 400$

Small charcoal pieces in clay, $810 \mathrm{~m}$ E of mouth of Corral Canyon, E-facing valley wall of Gully A.

General Comment: these dated fan deposits overlie marine terrace deposits $(115,000 \pm 15,000$ to $154,000 \pm 30,000$ yr, Szabo \& Rosholt, 1969). Dates fall into consistent pattern, although contamination by both modern and fossil carbon is suspected. Fan deposition probably began ca 10,000 to $20,000 \mathrm{BP}$.

\section{Laguna Alta series, California}

Peat samples $3.4 \mathrm{~m}$ below surface of peat deposit that formed in pond on San Andreas fault, NW part of Laguna Alta, San Mateo Co, California.

W.2561.

$2340 \pm 250$

Peat $\left(37^{\circ} 39^{\prime} 38^{\prime \prime} \mathrm{N}, 122^{\circ} 28^{\prime} 48^{\prime \prime} \mathrm{W}\right)$. Coll 1962 by M G Bonilla and $\mathrm{G} O \mathrm{O}$ Gates; subm by M G Bonilla.

W-2659.

$2690 \pm 250$

Peat ( $\left.37^{\circ} 39^{\prime} 33^{\prime \prime} \mathrm{N}, 122^{\circ} 28^{\prime} 42^{\prime \prime} \mathrm{W}\right)$. Coll 1962 by M G Bonilla, D M Hopkins, Clyde Wahrhaftig and D S McCulloch; subm by M G Bonilla.

General Comment (MGB): Laguna Alta was, before urbanization, a pond along San Andreas fault, and was almost certainly formed by movement along the fault. Radiocarbon date is minimum for period during which this trace of the fault has been active.

\section{Los Angeles damsite series, California}

Three samples from $\mathrm{N}$ wall of damsite, Van Norman Reservoirs area, N San Fernando Valley (34 $\left.17.75^{\prime} \mathrm{N}, 118^{\circ} 28.75^{\prime} \mathrm{W}\right)$, California. Coll 1972 by M G Bonilla, R F Yerkes, and R H Campbell; subm by M G Bonilla.

$\mathrm{W}-\mathbf{2 7 4 7}$.

$9580 \pm 300$

Organic matter, depth $3.6 \mathrm{~m}$, alt $333 \mathrm{~m}$, Unit 4 . 
W-2746.

$10,000 \pm 300$

Organic matter, 1.6m SSW of W2747, Unit 4.

General Comment (MGB): dates indicate that wet plant-promoting environment persisted at least $8000 \mathrm{yr}$.

\section{W.2745.}

$>40,000$

Wood, depth $9.3 \mathrm{~m}$, alt $327 \mathrm{~m}$, Unit 9 .

General Comment (MGB): dates are consistent with ages inferred from fossil molar of Paramylodon sp and with other radiocarbon dates from (Yerkes et al, 1974). These dates were used to estimate the age of faulting at damsite. Surficial deposits locally cut by faults are correlated with units stratigraphically underlying Unit 4 and overlying Unit 9. Displacement probably occurred $>10,000$ yr ago.

\section{W-2336. Buena Vista Slough, California}

$31,000 \pm 1000$

Fibrous wood from sequence of alluvial sand, silt, and clay, depth $18.6 \mathrm{~m}, .48 \mathrm{~km} \mathrm{NE}$ of Sta $3168+00$ of California Aqueduct, $4.8 \mathrm{~km} \mathrm{~S}$ of Button Willow, $43 \mathrm{~km} \mathrm{~W}$ of Bakersfield $\left(35^{\circ} 21^{\prime} 55^{\prime \prime} \mathrm{N}, 119^{\circ} 28^{\prime} 12^{\prime \prime}\right.$ W), California. Coll 1969 by Neal Crawford, California Dept Water Resources; subm by B E Lofgren. Comment (BEL): good correlation with other radiocarbon dates in Tulare and Buena Vista lakebeds (Croft, 1968, p B155). Suggests depositional continuity between the 2 lake basins, certainly by stream gravels, and probably by pluvial lake clays.

\section{Lake Bonneville series, Utah}

Shells and lake sediment exposed in dragline excavation, $960 \mathrm{~m} \mathrm{NE}$ of Danger Cave, NE of Wendover $\left(41^{\circ} 00^{\prime} \mathrm{N}, 114^{\circ} 00^{\prime \prime} \mathrm{W}\right)$, W Utah (Jennings, 1957). Coll and subm 1969 by H J Bissell, Brigham Young Univ, Provo, Utah.

W-2332.

$24.000 \pm 600$

Gastropods from $0.3 \mathrm{~m}$ mollusk bed, depth $2.1 \mathrm{~m}$, overlying silty clay unit of Provo Formation, Lake Bonneville Group (Bissell, 1963).

W-2335.

$8850 \pm 300$

Organic muck, depth $1.8 \mathrm{~m}$, underlain by $\mathrm{W}-2332$, overlain by $1.2 \mathrm{~m}$ lacustrine silt, and this by $.45 \mathrm{~m}$ alluvium and soil.

General Comment (HJB): gastropod bed is likely Provo Substage No. 1. A hiatus of some $15,000 \mathrm{yr}$ is represented after accumulation of shell bed and organic muck.

W-2353. Big Cottonwood Canyon, Utah

$770 \pm 200$

Wood (Pimus flexilis), Lake Catherine Cirque of Big Cottonwood Canyon, Brighton quad $\left(40^{\circ} 35^{\prime} \mathrm{N}, 111^{\circ} 36^{\prime} \mathrm{W}\right)$, Utah. Coll 1967 by Ted Arnow and Richard Van Horn; subm by Richard Van Horn. Comment $(\mathrm{RV})$ : date suggests limber pines grew in cirque during inter- 
stade between Temple Lake and historic glaciations (Richmond, 1962), the latter destroying pines on cirque floor but not those on rock ridges above ice. Date agrees with others from Rocky Mts which indicate interstade occurred ca AD $0-1400$.

\section{Alaska}

\section{W-2240. Emmikroak Creek, Alaska}

Wood in beach deposits $9 \mathrm{~m}$ above present level of Chukchi Sea, $1 \mathrm{~km} \mathrm{E}$ of Emmikroak Creek (68 $\left.08^{\circ} \mathrm{N}, 166^{\circ} 00^{\prime} \mathrm{W}\right)$, Alaska. Coll 1958 and subm by Reuben Kachadoorian. Comment (RK): minimum age for solifluction material that overlies beach cleposits. Minimum age for last sea-level rise.

\section{W-2288. Iliamna, Alaska}

Modern

Organic material in sand, depth $76 \mathrm{~cm}$, Augustine I. emerged beach deposit, $2.1 \mathrm{~km}$ SSE of entrance to S lagoon, and $1.9 \mathrm{~km} \mathrm{~N}$ of S Augustine VABM sta, Cook Inlet $\left(59^{\circ} 21^{\prime} \mathrm{N}, 153^{\circ} 31^{\prime} 30^{\prime \prime} \mathrm{W}\right)$, Alaska. Coll and subm 1967 by R L Detterman. Comment (RLD): together with date, $2650 \pm 250, \mathrm{~W}-2123(\mathrm{R}, 1970, \mathrm{v} 12, \mathrm{p} 330)$ gives maximum rate of uplift, 30 to $60 \mathrm{~cm} /$ century, along $W$ side of Cook Inlet. Modern age tends to confirm this rapid rate of uplift (Detterman \& Reed, 1973).

\section{Mt Michelson series, Alaska}

Wood and peat samples from MIt Michelson quad, NE Alaska. Subm by R L Detterman.

\section{W-2397.}

$6400 \pm 250$

Peat and plant remains in highly organic layer overlying ice wedge from raised terace, $2.6 \mathrm{~km}$ inland from Arctic coast, Marsh Creek $\left(69^{\circ} 57^{\prime}\right.$ $30^{\prime \prime} \mathrm{N}, 144^{\circ} 48^{\prime} 10^{\prime \prime} \mathrm{W}$ ). Coll 1969 by R L. Detterman. Comment (RLD): age represents beginning of Hypsithermal in N Alaska. The ice wedge is assumed a relic of Wisconsin glaciation, and not a result of more recent, minor advances in Brooks Range.

\section{W-2508.}

Wood from Picea $\log$ (id by R A Scott), Atlantic Richfield Prudhoe Bay State \#1 well, depth 175 to $180 \mathrm{~m}, 3 \mathrm{~km}$ NW of mouth of Putuligayuk R ( $\left.70^{\circ} 19^{\prime} 30^{\prime \prime} \mathrm{N}, 148^{\circ} 32^{\prime} \mathrm{W}\right)$. Coll 1970 by Atlantic Richfield Company. Comment (RLD): this minimum age is 1st indication of possible Sangamon age spruce forest on North Slope of Alaska. Sample came from unconsolidated sand and gravel unit, believed to be an old fluvial deposit during a low sea-level stand.

W-2586.

Complete re-run of W-2508.

W-2590.

Wood from small log, depth $10.5 \mathrm{~m}$, tributary of Niguanak R, $27.5 \mathrm{~km}$ SSW of Humphrey Point, Beaufort Sea, $\left(70^{\circ} 00^{\prime} \mathrm{N}, 143^{\circ} 00^{\prime} \mathrm{W}\right)$. Coll 1970 
by R L Detterman. Comment (RLD): confirms presence of spruce forest in $\mathrm{N}$ Alaska during Sangamon Interglaciation. Gravel at top of outcrop where sample was found is now considered Wisconsin outwash, and sands, silts, and gravel below are believed to be upper member of Gubik Formation. Date will help better define Gubik Formation and will make it a little older than originally defined (Black, 1964).

\section{W-2917. Harlequin Lake, Alaska}

$9320 \pm 350$

Marine pelecypods and barnacle shells atop ice-shove moraine, alt $54 \mathrm{~m}$, near SE shore of Harlequin Lake, $48 \mathrm{~km} \mathrm{SE}$ of Yakutat $\left(59^{\circ} 24^{\prime} \mathrm{N}\right.$, $138^{\circ}$ 57.5' W), Alaska. Coll 1967 by S R Welty, US Bur Public Rds, Juneau, Alaska; subm by L A Yehle. Comment (LAY): dates part of interval of marine submergence during early Holocene time when land apparently was still glacio-isostatically depressed because of resiclual effect of ice load during last major Pleistocene glaciation. Later, sample and enclosing material were transported by ancestral Yakutat Glacier and cleposited as a moraine.

\section{W-2292. Skagway, Alaska}

$2880 \pm 250$

Pelecypods from small pocket of shell accumulation on steep beclrock surface $9.6 \mathrm{~m}$ above MSI, $0.5 \mathrm{~km}$ NE of Yakutania Point, NW side of Skagway Harbor, Skagway (59 $\left.27^{\prime} 15^{\prime \prime} \mathrm{N}, 135^{\circ} 19^{\prime} 35^{\prime \prime} \mathrm{W}\right)$, Alaska. Coll 1968 by L A Yehle; subm by R W Lemke and L A Yehle. Comment (LAY): dates former sea level, controlled most likely by glacio-isostatic depression and rebound from Neoglacial ice load (Yehle \& Lemke, 1972, p 17).

\section{Haines series, Alaska}

Pelecypod shells from Haines, Alaska. Subm by R W Lemke and L A Yehle.

General Comment (LAY): dates late Pleistocene and Holocene glacioisostatic period of adjustment. Alt of deposit may be tectonically as well as glacio-isostatically controlled.

W.2291.

$9940 \pm 350$

Shells from floor of borrow pit, $10.5 \mathrm{~m}$ above MSL, $0.5 \mathrm{~km} \mathrm{~S}$ of junction of Sawmill Rd and Haines Hwy (59 $\left.19^{\circ} 56^{\prime \prime} \mathrm{N}, 135^{\circ} 28^{\prime} \mathrm{W}\right)$. Coll 1968 by L A Yehle.

W-2293.

$10,250 \pm 350$

Shells, $12 \mathrm{~m}$ below MSI, test hole $0.3 \mathrm{~km}$ SW of junction of Sawmill Rd and Haines Hwy (59 $\left.14^{\prime} 30^{\prime \prime} \mathrm{N}, 135^{\circ} 28^{\prime} 30^{\prime \prime} \mathrm{W}\right)$. Coll 1967 by J A McConaghy.

\section{W-2294.}

$11,020 \pm 400$

Shells from construction site, $15 \mathrm{~m}$ above MSL, along SW side Lutak Inlet, $5.6 \mathrm{~km} \mathrm{NW}$ of Haines (59 $\left.17^{\prime} 10^{\prime \prime} \mathrm{N}, 135^{\circ} 28^{\prime} 40^{\prime \prime} \mathrm{W}\right)$. Coll 1968 by L A Yehle (Lemke \& Yehle, 1972, p 13). 


\section{Stikine delta region series, Alaska}

Shells from Wrangell area, Alaska. Coll 1968 by L A Yehle; subm by R W Lemke and L A Yehle.

\section{W-2326.}

Pelecypod shells, $19.5 \mathrm{~m}$ above MSL, $0.8 \mathrm{~km}$ SE of Point Highfield, $\mathrm{S}$ embankment, overlooking Wrangell Airport runway, $1.6 \mathrm{~km} \mathrm{NNE}$ of

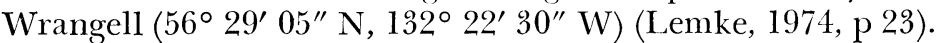

\section{W-2327.}

Barnacle fragments, $37.5 \mathrm{~m}$ above MSL, N facing roadcut, Mitkof Hwy, S Mitkof I., $16.8 \mathrm{~km}$ NW of Wrangell $\left(56^{\circ} 33^{\prime} 30^{\prime \prime} \mathrm{N}, 132^{\circ} 37^{\prime}\right.$ $\left.30^{\prime \prime} \mathrm{W}\right)$.

General Comment (LAY): these 2 samples provide further evidence of shoreline displacement in SE Alaska during late Quaternary. Emergence of land was caused by glacio-isostatic rebound but total emergence was reduced by eustatic sea-level rise and tectonic sinking of Stikine delta. Other tectonic effects probably had an important influence. Comparison between $\mathrm{W}-2327$ and $-1738,9970 \pm 300(\mathrm{R}, 1967, \mathrm{v} 9, \mathrm{p} 523)$ from $8.4 \mathrm{~m}$ above MSL, $3.2 \mathrm{~km}$ to NE, gives a crucle rate for net emergence of $1.34 \mathrm{~cm} / \mathrm{yr}$. This rate appears reasonable. Present-day net emergence based on tidal gauge records is about the same at Juneau $200 \mathrm{~km}$ to NW (Hicks \& Shofnos, 1965).

\section{Yakutat series, Alaska}

Samples from $0.3 \mathrm{~m}$ diamicton unit in intertidal zone of Lost $\mathrm{R}$ estuary at community of Lost R, $6.9 \mathrm{~km}$ SE of Yakutat Airport $\left(59^{\circ} 27^{\prime} \mathrm{N}\right.$, $\left.139^{\circ} 37^{\prime} \mathrm{W}\right)$, Alaska. Coll 1966 and subm by L A Yehle.

\section{W-2167.}

$500 \pm 250$

Detrital Wood.

\section{W-2598.}

$2180 \pm 250$

Pelecypod shells.

General Comment (LAY): detrital wood (W-2167) is close in age, $560 \pm$ 75, I-439 (R, 1966, v 8, p 163-164) to sheared off wood beneath major moraine $11.2 \mathrm{~km}$ NW, near mouth of Yakutat Bay (Yehle, 1975, p 39). To account for mixing of materials of 2 different ages within same deposit, following sequence is suggested. Wood was plowed up by the glacier and, because land was glacio-isostatically depressed below present sea level, subsequent deglaciation and melting of glacier was accompanied by calving, floating, and occasional grounding of icebergs. During in-place melting, waves and tidal currents would have jostled and washed the bergs, resulting in spreading-out and mixing of englacial debris with soft underlying deposits, one part of which contained marine shells (W-2598). 


\section{Seward Peninsula series, Alaska}

This study was made to establish time when certain forest and transition plants and animals reached their early Holocene limits in NW Alaska. Woods and sediments were coll from Seward Peninsula (SP) 19661970 by D M Hopkins; subm by D M Hopkins and C H Nelson. (McCulloch \& Hopkins, 1966).

\section{W-2810.}

$4290 \pm 250$

Lacustrine sediments exposed in bank of intramorainal pond, near SE of Lopp Lagoon, W SP (65 $\left.43^{\prime} 20^{\prime \prime} \mathrm{N}, 167^{\circ} 27^{\prime} 30^{\prime \prime} \mathrm{W}\right)$. Exposure is within an end moraine of late Wisconsin glaciation, York Glaciation of Sainsbury, (Sainsbury, 1967a, b). Comment (DMH): sample unexpectedly young. Exposure was interpreted in field as consisting of pre-glacial lakebeds overlain by drift of York Glaciation, which Sainsbury shows took place before 10,900 yr ago. Locality is too far in front of mountains to suggest that it was overridden by drift of Neoglacial age. Probably exposure is cut through sediments in a kettle lake that was later covered by colluvium from a nearby morainal knob.

\section{W-2808.}

$8080 \pm 300$

Beaver-chewed $\log$, NW side of mining cut at Mud Creek, near Candle, NE SP ( $\left.65^{\circ} 56^{\prime} 40^{\prime \prime} \mathrm{N}, 161^{\circ} 59^{\prime} 00^{\prime \prime} \mathrm{W}\right)$.

\section{W-2809.}

$$
\mathbf{8 3 1 0} \pm \mathbf{3 0 0}
$$

Stump rooted in buried turf, $3 \mathrm{~m}$ above $\mathrm{W}-2808$, same location.

General Comment (DMH): site lies W of present-day forest boundary and $\mathrm{W}$ of present limit of beaver. Both samples indicate evidence of warm climate from Mud Creek 10,000 to $8000 \mathrm{yr}$ ago; date of $3600 \pm 500$, L-117F (Broecker et al, 1956, p 157) from same location is discredited.

\section{W-2592.}

$8360 \pm 300$

Stem of large willow shrubs, id by Virginia Page, in sedge peat filling ice-wedge pseudomorphs in bluffs on $S$ shore of Lopp Lagoon, W SP $\left(65^{\circ} 40^{\prime} 20^{\prime \prime} \mathrm{N}, 167^{\circ} 54^{\prime} 02^{\prime \prime} \mathrm{W}\right)$. Comment (DMH): records growth of large willow shrubs near Bering Strait, in region that now lacks shrubs of any kind.

\section{W-2596.}

$\mathbf{8 4 8 0} \pm 300$

Birch $\log$ in fossil beaver dam from wave-cut bluff, mouth of Old Wound, N SP $\left(66^{\circ} 29^{\prime} 55^{\prime \prime} \mathrm{N}, 164^{\circ} 46^{\prime} 30^{\prime \prime}\right.$ W). Comment (DMH): represents $\mathrm{W}$-most fossil occurrence of birch during early Holocene warm period.

\section{W-2619.}

$9190 \pm 350$

Large $\log$ from bank of thaw lake, $8 \mathrm{~km} \mathrm{SE}$ of Northwest Corner, N SP $\left(66^{\circ} 31^{\prime} 31^{\prime \prime} \mathrm{N}, 164^{\circ} 15^{\prime} 50^{\prime \prime} \mathrm{W}\right)$. Comment (DMH): sample coll at $\mathrm{W}$-most occurrence of large freshwater mollusk, Anodonta beringiana, during early Holocene warm period. 
W-2620.

$9625 \pm 350$

Large pieces of wood from thaw lake deposit on coast of $\mathrm{N}$ SP, between Cape Deceit and Rex Point (66 $06^{\circ} 00^{\prime \prime} \mathrm{N}, 163^{\circ} 03^{\prime} 18^{\prime \prime} \mathrm{W}$ ). Comment (DMH): probably represents W-most early Holocene fossil occurrence of Populus.

\section{W-2804.}

$28,700 \pm 1000$

Organic resiclue from loess exposed in wave-cut bluff at Northwest Corner Light, N SP (66 $\left.34^{\prime} 54^{\prime \prime} \mathrm{N}, 164^{\circ} 27^{\prime} 17^{\prime \prime} \mathrm{W}\right)$. Comment (DMH): older than expected and surprising in that it falls onto a period for which I had expected evidence of interstadial with sea level only slightly lower than at present, glaciers retracted, and aeolian activity reduced. Instead, this date indicates that intense aeolian activity on N SP-Kotzebue Sound area was not confined to late $W$ isconsin time but evidently persisted throughout Wisconsin cold cycle.

\section{Devil Mt series, SP, Alaska}

This study was made to establish tephrochronology of areas affected by ashfalls from Devil Mt (DMt). These upper Pleistocene ashfalls can be recognized widely in Kotzebue Sound. Col 1966 and 1970 and subm by D M Hopkins.

\section{W-2800.}

$9350 \pm 350$

Peaty material overlain by ashfall from $S$ crater, from bluffs at SW shore of N DMt Lake (66 $\left.26^{\circ} 36^{\prime \prime} \mathrm{N}, 164^{\circ} 31^{\prime} 45^{\prime \prime} \mathrm{W}\right)$.

\section{W-2802.}

$9410 \pm 350$

Wood pieces, $0.6 \mathrm{~m}$ below $\mathrm{W}-2800$.

W-2803.

Peaty material, $0.9 \mathrm{~m}$ below $\mathrm{W}-2802$.

W-2801.

$11,610 \pm 500$

Peaty material, $0.6 \mathrm{~m}$ below $\mathrm{W}-2803$, underlain by ashfall from $\mathrm{N}$ crater, DMt.

General Comment (DMH): DNt Lake consists of 2 intersecting maars. $\mathrm{S}$ maar erupted after $9350 \mathrm{BP}$ and $\mathrm{N}$ one erupted prior to $11,600 \mathrm{BP}$, but after 14,500, W-2806. Loess fall ended between time of deposition of $\mathrm{W}-2803$ and -2802 , са $10,000 \mathrm{BP}$, but another sample, W-2805, indicated that 11,000 вP would be better estimate of end of loess fall.

\section{W-2806.}

$14,490 \pm 400$

Screen residue from lakebeds exposed in cut bank of Espenberg $\mathrm{R}$ (ER) $\left(66^{\circ} 31^{\prime} 50^{\prime \prime} \mathrm{N}, 164^{\circ} 00^{\prime} 12^{\prime \prime} \mathrm{W}\right)$. Comment (DMH): age as expected. Sample was coll just below 1st appearance of DMIt ash and thus provides close approx of date of ashfall.

\section{W-2807.}

$25,390 \pm 800$

Well-macerated peat, thought to be buried turf, involved in icewedge collapse in exposure on ER $\left(66^{\circ} 31^{\prime} 20^{\prime \prime} \mathrm{N}, 164^{\circ} 00^{\prime} 20^{\prime \prime} \mathrm{W}\right)$. 
Comment (DMH): sample unexpectedly old. In field ash layer was thought to be identical to ash layer of W-2806 and ice-wedge collapse was thought to have formed during early Holocene warm period. Redeposition of older peat seems improbable. Apparently, ash in this sect is probably identical with ash near Kougachuk Creek dated 42,000 yr.

W-2670.

$>42,000$

Stems and roots of birch shrubs buried beneath fresh ashfall, exposed sea bluffs, $0.5 \mathrm{~km} \mathrm{~N}$ of mouth of Kougachuk Creek, N SP $\left(66^{\circ} 15^{\prime} 54^{\prime \prime} \mathrm{N}\right.$, $\left.163^{\circ} 49^{\prime} 52^{\prime \prime} \mathrm{W}\right)$. Comment (DMH): sample is much older than anticipated. I had thought this ash layer was same as that of W-2806. Evidently, ash layer at Kougachuk Creek was erupted earlier and from another of numerous maars and cinder cones of area, most probably from South Killeak Iake. But an unresolved problem remains: why is there little or no loess above this ancient ash layer?

General Comment (DMH): there are 3 ash horizons representing 3 maar eruptions in Espenberg region during Wisconsin and Holocene time. Dates, taken together with studies of the freshwater mollusks, also show that post-glacial warming was felt earlier than previously thought. Mollusks reponded as early as 11,400 yr ago, although forest plants clicln't begin to appear until ca $9800 \mathrm{yr}$ ago.

\section{Espenberg River series, SP, Alaska}

This series was submitted to clarify age relationships among Quaternary deposits exposed along Espenberg R (ER), a sluggish stream that heads a short distance inland from a subdued slope evidently marking Pelukian (Sangamon) shoreline on N SP. The river crosses a plain underlain by Pelukian beach and lagoonal deposits, exposed at river level, mantled by medium sand, 2 or $3 \mathrm{~m}$ thick, that was evidently deposited as coastal dunes, overlain in turn by ca $10 \mathrm{~m}$ periglacial loess and fine sand that was deposited or redeposited in thaw lakes. Woods and sediments were coll and subm 1970 by D M Hopkins.

\section{W-2805.}

$11,550 \pm 350$

Small wood fragments, base of thaw lake deposit exposed in cut bank of ER $\left(66^{\circ} 30^{\prime} 42^{\prime \prime} \mathrm{N}, 164^{\circ} 01^{\prime} 38^{\prime \prime} \mathrm{W}\right)$. Comment (DMH): was thought to be Holocene, but this age is plausible. Sample coll from base of thaw lake deposits that contain rich "post-glacial" biota and that accumulated after end of loess fall. Sediment underlain by ca $1 \mathrm{~m}$ loess and then by ash dated elsewhere on Espenberg $\mathrm{R}$ as ca 14,500 yr (W-2806).

W-2883.

$21,600 \pm 600$

Organic material, screen-washed from thaw-lake sediments, cut bank ER $\left(66^{\circ} 31^{\prime} 21^{\prime \prime} \mathrm{N}, 164^{\circ} 00^{\prime} 37^{\prime \prime} \mathrm{W}\right)$.

W-2879.

Organic material at base of thaw-lake sequence, artificial excavation in cut bank of $\mathrm{ER}\left(66^{\circ} 30^{\prime} 01^{\prime \prime} \mathrm{N}, 164^{\circ} 05^{\prime} 53^{\prime \prime} \mathrm{W}\right)$. 
W-2880.

$16,950 \pm 500$

Organic debris, $0.5 \mathrm{~m}$ below $\mathrm{W}-2879$, top of silt unit, probably aeolian, containing lenses of sand and lenses and fragments of peat, representing fragments of buried turf.

General Comment (DMH): these 2 samples, W-2879 and -2880, appear to be transported, either in the field or during examination for micro-fossils.

W-2881.

$>36,000$

Fossil wood, thaw-lake sediments, cut bank ER $\left(66^{\circ} 30^{\prime} 38^{\prime \prime} \mathrm{N}, 164^{\circ}\right.$ $02^{\prime} 20^{\prime \prime} \mathrm{W}$ ). Comment (DMH): high sand-silt content and lack of pumice suggest lake existed prior to last eruption at DMt Lake and during period of Pleistocene aeolian activity. But rich biota and presence of shrubsize twigs indicate lake is not contemporary with maximum cold period.

\section{W-2882.}

Peat lumps, possibly buried turf, interbedded with silt and lenses of very fine sand, $1.8 \mathrm{~m}$ below $\mathrm{W}-2881$. Comment (DNH): depauperate flora suggest full-glacial conditions.

\section{W-2878.}

Twigs in thin-bedded lacustrine silt interbedded with sand, containing distinctive Pelukian (Sangamon) fauna, cut bank of ER (66 $36^{\circ} 31^{\prime \prime}$ $\left.\mathrm{N}, 164^{\circ} 00^{\prime} 12^{\prime \prime} \mathrm{W}\right)$.

\section{W-2884.}

$>31,000$

Screen residue, $2.4 \mathrm{~m}$ below $\mathrm{W}-2806$, at base of lake beds.

General Comment (DMH): series shows that some thaw lakes existed during early Wisconsin time, beyond range of radiocarbon dating and that others existed as recently as 11,500 BP (active thaw lakes still exist, away from river). Periglacial loess and fine sand has been deposited more or less continuously throughout Wisconsin Glaciation. Older 2 of 3 dated ash beds occur in some lake deposits. Medium sand of assumed coastal dunes is of early Wisconsin age, and beyond range of radiocarbon activity.

\section{North Bering Sea series, Alaska}

This study was made to establish transgressive history of region (Nelson, 1976; Nelson et al, 1973; 1974; Nelson \& Creager, 1977). Shell samples, mainly shallow, burrowing and epifaunal species, from base of N Bering Sea were coll 1968-69 with box cores and subm by $\mathrm{C} \mathrm{H}$ Nelson.

W-2682.

$700 \pm 250$

Shells (Neptumea) in coarse transgressive sand, overlain by clayey silt, water depth $42 \mathrm{~m}$, seaward side of isolated basin, $16 \mathrm{~km}$ NNE of Singikpo Cape, central St Iawrence I. (63 43.7' N, $169^{\circ} 54.2^{\prime} \mathrm{W}$ ).

\section{W-2467.}

$700 \pm 200$

Shell fragments (Macoma calcerea) in sand, overlain by $10 \mathrm{~cm}$ fine sand, water depth $37.5 \mathrm{~m}\left(63^{\circ} 35.4^{\prime} \mathrm{N}, 169^{\circ} 58.4^{\prime} \mathrm{W}\right)$. 
Infaunal shells (Hyatella Arctica, Mya Truncata) isolated in basal sands, overlain by $11 \mathrm{~cm}$ undisturbed laminated sand, water depth $31 \mathrm{~m}$, $48 \mathrm{~km} \mathrm{~S}$ of Cape Prince of Wales, $43 \mathrm{~km}$ of Port Clarence $\left(65^{\circ} 11.2^{\prime} \mathrm{N}\right.$, $\left.167^{\circ} 53.2^{\prime} \mathrm{W}\right)$

W-2462.

$750 \pm 200$

Shells in silty sand, water depth $24.6 \mathrm{~m}\left(64^{\circ} 13.9^{\prime} \mathrm{N}, 166^{\circ} 14.9^{\prime} \mathrm{W}\right)$.

W-2681.

$\mathbf{7 7 0} \pm \mathbf{2 5 0}$

Shells at contact between "transgressive" and fine sand, water depth $50 \mathrm{~m}, 78 \mathrm{~km} \mathrm{SW}$ of Cape Prince of Wales $\left(65^{\circ} 04.5^{\prime} \mathrm{N}, 169^{\circ} 17.7^{\prime} \mathrm{W}\right)$.

W-2466.

$980 \pm 200$

Shell fragments in muddy sandy silt, water depth $30.6 \mathrm{~m}\left(64^{\circ} 24.0^{\prime} \mathrm{N}\right.$, $165^{\circ} 35.0^{\prime} \mathrm{W}$ )

\section{W-2464.}

$1040 \pm 200$

Shell fragments in shell bed buried by fine sand, depth $42.6 \mathrm{~m}$ $\left(63^{\circ} 41.0^{\prime} \mathrm{N}, 170^{\circ} 11.0^{\prime} \mathrm{W}\right)$.

\section{W.2684.}

$1400 \pm 250$

Rounded and abraded shells in basal pebbly clay layer, water depth $47 \mathrm{~m}, 43 \mathrm{~km} \mathrm{~S}$ of Cape Prince of Wales, $54 \mathrm{~km} \mathrm{~W}$ of Port Clarence $\left(65^{\circ}\right.$ $\left.13.6^{\prime} \mathrm{N}, 168^{\circ} 06.6^{\prime} \mathrm{W}\right)$.

General Comment (CHN): young dates suggest very limited or nondeposition of Holocene sediments in offshore regions.

\section{W.2685.}

$1690 \pm 250$

Broken and rounded shells in beach gravel, water depth $30 \mathrm{~m}, 27 \mathrm{~km}$ $\mathrm{N}$ of Northwest Cape off $\mathrm{W}$ end of St Lawrence I $\left(63^{\circ} 58.5^{\prime} \mathrm{N}, 171^{\circ}\right.$ 28.2' W).

\section{Norton Sound series, Alaska}

Shell, wood, and peat samples from below sea floor, Norton Sound, Bering Sea were coll 1967-70 and subm by C H Nelson and D M Hopkins.

W-2301.

$340 \pm 200$

Shells at water depth 25 to $32 \mathrm{~m}$, core depth 0 to $5 \mathrm{~cm}$, offshore at Nome $\left(65^{\circ} 00.5^{\prime} \mathrm{N}, 168^{\circ} 01.5^{\prime} \mathrm{W}\right)$.

W-2325.

$10,250 \pm 350$

Wood picked from drill cuttings, 0 to $420 \mathrm{~cm}$ in core, water depth 20.4 to $18.6 \mathrm{~m}$, old outwash fan of Nome R, just $\mathrm{E}$ of Nome $\left(64^{\circ} 27.4^{\prime} \mathrm{N}\right.$, $\left.165^{\circ} 25^{\prime} \mathrm{W}\right)$.

\section{W-2686.}

$10,120 \pm 350$

Reworked, subaerial fine peat, in Marine Yukon silts, core depth 19 to $23 \mathrm{~cm}$, water depth $18.7 \mathrm{~m}$, center of Norton Sound $\left(63^{\circ} 42.7^{\prime} \mathrm{N}\right.$, $\left.163^{\circ} 03.2^{\prime} \mathrm{W}\right)$. 
W-2555.

$$
10,500 \pm 300
$$

Peat, core depth 33 to $40 \mathrm{~cm}$, water depth $20 \mathrm{~m}$, same core as $\mathrm{W}-2686$. General Comment (DMH): indicates minimum rate of Holocene sedimentation 2cm/100 yr (Nelson et al, 1974, Nelson \& Creager, 1977, Hopkins, 1973). Low rate of Holocene sedimentation in Norton Sound, but relatively high rate in Chukchi Sea suggests displacement and bypassing of Yukon sediment over Bering shelf.

W-2680.

$1350 \pm 500$

Mollusks, depth $40 \mathrm{~cm}$ in sequence of Yukon silt, water depth $14 \mathrm{~m}$ $\left(63^{\circ} 41.4^{\prime} \mathrm{N}, 161^{\circ} 11.6^{\prime} \mathrm{W}\right)$.

W.2534.

$>30,000$

Peat under Yukon silt, core depth $24 \mathrm{~cm}$, water depth $36.5 \mathrm{~m}, 36.8 \mathrm{~km}$ W of Point Spencer $\left(65^{\circ} 05.1^{\prime} \mathrm{N}, 167^{\circ} 43.4^{\prime} \mathrm{W}\right)$.

W-2115.

Wood in alluvium, core depth 3.6 to $5.4 \mathrm{~m}$ below sea floor, overlain by Holocene sand, water depth $13 \mathrm{~m}\left(64^{\circ} 31.3^{\prime} \mathrm{N}, 165^{\circ} 40.3^{\prime} \mathrm{W}\right)$. Comment $(\mathrm{CHN})$ : upper Pleistocene stratigraphy related auriferous deposits.

W-2116.

Shells in marine nearshore sand, core depth 6.6 to $8.4 \mathrm{~m}$ below sea floor, water depth $12.9 \mathrm{~m}\left(64^{\circ} 26.5^{\prime} \mathrm{N}, 165^{\circ} 06.6^{\prime} \mathrm{W}\right)$.

\section{E. Miscellaneous Samples}

W-2287. Jarvis Island, Pacific

$2530 \pm 250$

Dolomitized lagoonal mud underlying gypsum-algal mat surficial layers on Jarvis $\mathrm{I}\left(01^{\circ} 00^{\prime} \mathrm{N}, 160^{\circ} 00^{\prime} \mathrm{W}\right)$, Pacific Ocean. Subm by S O Schlanger, Univ California, Riverside. Comment (SOS): 1st recent dolomite from Pacific.

\section{W-2238. Monrovia, Liberia}

$6160 \pm 600$

Clay with very abundant plant remains, within New Georgia Clay, depth 4.2 to $4.5 \mathrm{~m}$, near Monrovia $\left(06^{\circ} 22^{\prime} \mathrm{N}, 10^{\circ} 47^{\prime} \mathrm{W}\right)$, Liberia. Coll 1967 and subm by L V Blade. Comment (LVB): deposit is probably estuarine lagoonal. Entire sequence of sediments is Quaternary (Blade, 1970 , p 8).

\section{RFFERENCES}

Baker, R G, 1976, Late Quaternary vegetation history of the Yellowstone Lake Basin, Wyoming: US Geol Survey Prof Paper 729-E, 48 p.

Bender, M M, Bryson, R A, and Baerreis, D A, 1970, University of Wisconsin radiocarbon dates VII: Radiocarbon, v 12, p 335-345.

Bingham, J W, Londquist, C J, and Baltz, E H, 1970, Geologic investigation of fault ing in the Hanford region, Washington: US Geol Survey Open-File, $104 \mathrm{p}$.

Birkeland, P W, 1974, Pedology, weathering and geomorphological research: Oxford, Oxford Univ Press, $282 \mathrm{p}$.

Bissell, H J, 1963, Lake Bonneville: Geology of southern Utah valley, Utah: US Geol Survey Prof Paper 257-B, p 101-130. 
Black, R F, 1964, Gubik Formation of Quaternary age in northern Alaska: US Geol Survey Prof Paper 302-C, $91 \mathrm{p}$.

Black, R F, and Rubin, Meyer, 1967-68, Radiocarbon dates of Wisconsin: Wisconsin Acad Sci, Arts and Letters, v 56, p 99-115.

Blade, L V, 1970, Geology of the Bushrod Island-New Georgia clay deposit near Monrovia, Liberia: US Gcol Survey Open-File Rept, 35 p.

Broecker, W S, Kulp, J L, and Tucek, C S, 1956, Lamont natural radiocarbon measurements III: Science, v 124, p 154-165.

Clayton, Lee 1962, Glacial geology of Logan and McIntosh counties, North Dakota: North Dakota Geol Survey Bull 37, 84 p.

Croft, M G, 1968, Geology and radiocarbon ages of late Pleistocene lacustrine clay deposits, southern part of San Joaquin valley, California: US Geol Survey Prof Paper 600-B, p B151-B-156.

Detterman, R L and Reed, B L, 1973, Surficial deposits of the Iliamna quadrangle, Alaska: US Geol Survey Bull 1368-A, 64 p.

Hicks, S D and Shofnos, William, 1965, The determination of land emergence from sea level observations in southeast Alaska: Jour Geophys Research, v 70, p 33153320 .

Hopkins, D M, 1973, Sea level history in Beringia during the past 250,000 years: Quaternary Research, v 3, p 520-540.

Ives, P C, Levin, Betsy, Oman, C L, and Rubin, Meyer, 1967, US Geological Survey radiocarbon dates IX: Radiocarbon, v 9, p 505-529.

Ives, P C, Levin, Betsy, Robinson, R D, and Rubin, Meyer, 1964, US Geological Survey radiocarbon dates VII: Radiocarbon, v 6, p 37-76.

Jennings, J D, 1957, Danger Cave: Univ Utah, Dept Anthropology, Anthropol Papers No. 27,328 p.

Lemke, R W, 1974, Reconnaissance engineering geology of the Wrangell area, Alaska, with emphasis on evaluation of earthquake and other geologic hazards: US Geol Survey Open-File Rept No. 1968, 103 p.

Lemke, R W and Yehle, L A, 1972, Regional and other general factors bearing on evaluation of earthquake and other geological hazards to coastal communities of southeastern Alaska: US Geol Survey Open-File Rept, 99 p.

Marsters, Beverly, Spiker, Elliott, and Rubin, Meyer, 1969, US Geological Survey radiocarbon dates X: Radiocarbon, v 11, p 210-227.

McCulloch, David and Hopkins, David, 1966, Evidence for an early Recent warm interval in northwestern Alaska: Geol Soc America Bull, v 77, p 1089-1107.

McFarlan, A C, 1943, Geology of Kentucky: Baltimore, Maryland, Waverly Press, 531 p.

Nelson, C H, 1976, Sedimentary facies and structures of Bering epicontinental shelf (abs): Am Assoc Petroleum Geologists Bull, v 60, p 702.

Nelson, C H and Creager, J S, 1977, Displacement of Yukon-derived sediment from Bering Sea to Chukchi Sea during Holocene time: Geology, v 5, p 141-146.

Nelson, C H, Hopkins, D M, and Scholl, D W, 1974, Cenozoic sedimentary and tectonic history of the Bering Sea, in: Hood, D W, and Kelley, E J, (eds), Oceanography of the Bering Sea: Inst Marine Sci City Univ Alaska Press, p 485-516.

Nelson, C H, Larsen, B R, and Rowland, R W, 1973, Late Holocene sediment dispersal in northeastem Bering Sea (abs): Am Geophys Union, v 54, p 1122.

Peterson, N V, and Groh, E A, (eds), 1965, State of Oregon lunar geological ficld conference guide book: State of Oregon Dept Geol Bull, v 57, 51 p.

Richmond, G M, 1962, Glaciation of Little Cottonwood and Bells canyons, Wasatch Mountains, Utah: US Geol Survey Prof Paper 454-D, 41 p.

Richmond, G M, Fryxell, Roald, Neff, G E, and Weis, P L, 1965, The Cordilleran ice sheet of the northern Rocky Mountains, and related Quaternary history of the Columbian plateau, in: Wright Jr, H E and Frey, D G, (eds), The Quaternary of the United States: Princeton, New Jersey, Princeton Univ Press, p 231-242.

Sainsbury, C L, 1967a, Upper Pleistocene features in the Bering Strait area: US Geol Survey Prof Paper 575-1), p D203-D212.

1967b, Quaternary geology of western Seward Peninsula, Alaska, in: Hopkins, DM, (ed), The Bering Land Bridge: Stanford, California, Stanford Univ Press, p 121-143.

Sirkin, L A and Minard, J P, 1972, Late Pleistocene glaciation and pollen stratigraphy in northwestern New Jersey: US Geol Survey Prof Paper 800-D, p D51-D56. 
Spiker, Elliott, Kelley, Lea, Oman, Charles, and Rubin, Meyer, 1977, US Geological Survey radiocarbon dates XII: Radiocarbon, v 19, p 332-353.

Steece, F V, 1965, Illinoian age drift in southeastern South Dakota: South Dakota Acad Sci, v 44, p 62-71.

Sullivan, B M, Spiker, Elliott, and Rubin, Meyer, 1970, US Geological Survey radiocarbon dates XI: Radiocarbon, v 12, p 319-334.

Szabo, B J and Rosholt, J N, 1969, Uranium-series dating of Pleistocene molluscan shells from southern California-an open system model: Jour Geophys Research, v 74, p 3253-3260.

Trautman, M A and Willis, E H, 1966, Isotopes, Inc radiocarbon measurements V: Radiocarbon, v 8, p 161-203.

Yehle, L A, 1975, Preliminary report on the reconnaissance engineering geology of the Yakutat area, Alaska, with emphasis on evaluation of earthquake and other geologic hazards: US Geol Survey Open-File Rept No. 75-529, 136 p.

Yehle, L A and Lemke, R W, 1972, Reconnaissance engineering geology of the Skagway area, Alaska, with emphasis on evaluation of earthquake and other geologic hazards: US Geol Survey Open-File Rept, 108 p.

Yerkes, R F and Wentworth, C M, 1965, Structure, Quaternary history, and general geology of the Corral Canyon area, Los Angeles County, California: US Geol Survey Open-File Rept, 215 p.

Yerkes, R F, Bonilla, M G, Youd, T L, and Sims, J D, 1974, Geologic environment of the Van Norman Reservoirs area, northern San Fernando Valley, California: US Geol Survey Circular 691-A, 35 p. 